\title{
COVID-19 in North Korea and Its Effect on the Cooperation of North and South Korea in the Field of Health Care
}

\author{
Byoung Yoong $K A N G^{*}$
}

\begin{abstract}
COVID-19 is an infectious respiratory disease that first appeared in December 2019 in Wuhan, China and first spread throughout the country and then worldwide. WHO Director-General Tedros Adhanom Ghebreyesus, concerned about the rapid spread of COVID-19, officially declared a global pandemic on March 11, 2020. North Korea (Democratic People's Republic of Korea) barred foreign tourists from China on January 21, 2020, and then completely closed its border with China.

In this article, I will explore the impact of COVID-19 on North Korean society and research the cooperation plan between South and North Korea. I will also briefly introduce in the post-COVID-19 period. To better understand the health care system and health conditions in North Korea, I will first analyse the infectious disease management system and, in the context of this, then try to investigate in detail how COVID-19 has affected North Korea. From an economic point of view, I will examine the changes in economic cooperation between North Korea and China, and then try to explain the social changes caused by restrictions on movement and lack of goods, and the political situation in North Korea during the COVID-19 crisis.

Finally, I will try to research the situation facing North Korea and suggest a way for cooperation between South and North Korea in the future. The basic aim of this research is to find a useful alternative for joint cooperation in the field of health care and safety and to improve cooperation between South and North Korea in the post-COVID-19 era.
\end{abstract}

Keywords: North Korea, South Korea, COVID-19, infectious diseases, pandemic, North Korean health, South Korean health, North Korean society, inter-Korean cooperation, post-COVID-19

Byoung Yoong KANG, Chair of Korean Studies, Department of Asian Studies, University of Ljubljana. Email address: oddyoong@yahoo.com

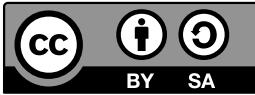




\section{COVID-19v Severni Koreji ter njegov vpliv na sodelovanje med Južno in Sev- erno Korejo na področju zdravstva}

\section{Izvleček}

Koronavirusna bolezen 2019 (COVID-19) je nalezljiva bolezen dihal, ki se je prvič pojavila decembra 2019 v Vuhanu na Kitajskem in se najprej razširila po celotni Kitajski, nato pa po vsem svetu. Generalni direktor Svetovne zdravstvene organizacije (WHO) Tedros Adhanom Ghebreyesus je, močno zaskrbljen zaradi hitrega širjenja bolezni COVID-19 po vsem svetu, 11. marca 2020 uradno razglasil globalno pandemijo.

Severna Koreja (Demokratična ljudska republika Koreja) je 21. januarja 2020, po izbruhu COVID-19 na Kitajskem, onemogočila vstop tujim turistom, naslednji dan pa popolnoma zaprla mejo s Kitajsko. 28. januarja 2020 je sprejela hitre in odločne ukrepe, med drugim je vzpostavila Nacionalni sistem za urgentno preprečevanje epidemije. Pojav COVID-19 je, skupaj s sankcijami Organizacije združenih narodov (OZN) proti Severni Koreji, zadal močan udarec severnokorejskemu gospodarstvu, vplival pa je tudi na družbo in politiko države.

V članku bom raziskal vpliv COVID-19 na severnokorejsko družbo in preučil načrt sodelovanja, ki bi ga morali uvesti Južna in Severna Koreja v času po COVID-19. Za lažje razumevanje zdravstva in zdravstvenih razmer v Severni Koreji bom najprej analiziral sistem obvladovanja nalezljivih bolezni in $\mathrm{v}$ okviru tega nato poskušal podrobno raziskati, kako je COVID-19 vplival na Severno Korejo. $Z$ gospodarskega vidika bom preučil spremembe $\mathrm{v}$ gospodarskem sodelovanju med Severno Korejo in Kitajsko, nato pa poskušal razložiti tudi družbene spremembe, ki sta jih povzročila omejitev gibanja in pomanjkanje dobrin, ter politične razmere v Severni Koreji v času krize COVID-19.

$\mathrm{Na}$ koncu bom poskušal preučiti razmere, s katerimi se sooča Severna Koreja, in predlagal način za sodelovanje med Južno in Severno Korejo ter skupno obvladovanje razmer v prihodnosti. Temeljni cilj te raziskave je najti koristno alternativo za skupno sodelovanje na področju zdravstva in varnosti ter izboljšanje sodelovanja med Južno in Severno Korejo v obdobju po COVID-19.

Ključne besede: Severna Koreja,Južna Koreja, COVID-19, nalezljive bolezni, pandemija, severnokorejsko zdravstvo, južnokorejsko zdravstvo, severnokorejska družba, medkorejsko sodelovanje, čas po COVID-19

\section{Preface}

The coronavirus disease 2019 (hereafter referred to as COVID-19) first appeared in Wuhan, China in late 2019 and spread globally from there. On March 11, 2020, the general director of the World Health Organization (WHO) Tedros Adhanom Ghebreysus was convinced that COVID-19 would spread around the world, and therefore declared a pandemic and called upon the world to cooperate 
and strive for a joint response. By December 12, 2020, COVID-19 was present in 220 countries, 1,594,775 people had died and 71,081,563 were confirmed as having been infected (JUH CSSE 2020). The pandemic has greatly affected all fronts of our lives, in terms of society, economics, politics and culture. COVID-19 does not acknowledge borders, races, nationalities, ages, or genders.

Even the Democratic People's Republic of Korea (North Korea) could not escape the global pandemic. The spread of infectious diseases in North Korea, which has a weak health care system and health care infrastructure, poses a risk that seriously threatens the functioning of state power. The United Nations Security Council sanctions against North Korea have hampered the development of the North Korean economy, while the spread of the infectious disease has further worsened the lives of North Koreans (Cho Young-Ki 2020,173). North Korean authorities recognized the seriousness of the COVID-19 pandemic, and the existing sanitation and preventive care system was replaced by the National System for the Urgent Prevention of the Epidemic. To prevent the spread of infectious diseases, North Korea closed all land, sea, and air routes, and also declared that they would implement thorough disinfection, preventive measures, and preventive health lectures (Hwang 2020, 21). Despite this, the end of January and early February 2020 saw the death of three patients suspected of having COVID-19. However, the official reason for death was given by the hospital as "acute pneumonia" and not COVID-19, and the hospital did not release further details of the deceased, who were being treated for high fevers, and instead declared them confidential, also keeping them secret from the WHO (Jang 2020, 3). On November 9, 2020, Edvin Salvador, the representative of the WHO in Pyongyang, gave an interview to the American Free Asia radio station (Radio Free Asia, RFA), quoted the words of the North Korean Ministry of Health and said that as of October 29, 2020, they had tested 12,072 people for COVID-19 and all of them were negative (Yonhapnews 2020). Thus, the North Korean Ministry of Health officially stated that they had no confirmed cases of infection. Still, the South Korean Minister of Foreign Affairs Kang Kyung-wha attended the International Institute for Strategic Studies' conference on December 5, 2020 in Manami, Bahrain, and said it is hard to believe that there are no confirmed cases of COVID-19 in North Korea. Kim Yojong, the First Deputy of the Workers' Party of Korea (WPK) (de facto number two in North Korea) vehemently denied this (Maeil Business Newspaper 2020), and reiterated that there are no COVID-19 infections in North Korea.

Nevertheless, North Korea was unlikely to be an exception in the great crisis facing all of humanity due to the spread of COVID-19. Recently, there have been increased reports of North Korean cyberattacks not only on South Korean pharmaceutical companies, but also other pharmaceutical companies that develop 
vaccines for the disease, such as AstraZeneca. North Korea is attempting to gain information in order to develop their own vaccine. At the same time the country has also tightened border controls on that were already closed, including the demilitarized region between north and south (Jeong Yong-su 2020). Such actions prove that North Korea is aware of the severity of the COVID-19 pandemic and seeks different ways to overcome the disease.

North Korea's health care system almost completely collapsed in the early 1990s, and has still not fully recovered (Hwang 2020, 21). To better understand the current North Korean conditions, we must first explain how the North Korean political system addresses epidemics, and then we can better explain the difficult situation facing North Korea because of COVID-19. Then we will discuss how it was possible to develop cooperation between North and South Korea in the field of health care and to create a common system for health and safety in the postCOVID-19 period.

\section{Health Care in North Korea}

\section{The General Understanding of the North Korean Health Care}

Choi, Kim and Hwang (2006) list five characteristics of the North Korean health care system. At first glance North Korea has a "system of free health care for all citizens" and encourages citizens to believe that the socialist social order is beneficial to them. In 1947, the state announced a system of free health care in accordance with the law on Social Security and started to implement it in 1953. In February 1960 they also adopted the resolution on the implementation of a comprehensive and universal free health care system (ibid., 22-24). Nevertheless, some claim that contrary to the statements of the authorities, the health care system in North Korea is not functioning as it should (ibid., 27). Refugees who escaped to South Korea and worked in the health care sector have revealed that the facts about health care in the North are not even close to what is claimed by the government (Nam Sung-wook 2020).

Secondly, North Korean health care policy emphasizes preventive medicine. When the Supreme Leader North Korean Kim Il-Sung announced in 1966 that "socialist medicine is preventive medicine", the entire country increased preventive behaviours against infectious diseases and measures related to this (Hwang 2020, 24). In order to improve living and working conditions, the state has conducted various campaigns and worked to reduce environmental pollution. The North Korean authorities claim that they expend much effort to carry out the 
continuous research and development of preventive medicine (Seung 1986, 77109). There are two reasons that could explain why socialist countries focus on preventive medicine.

1. Preventive care means a lower social cost than medical treatment

2. The population can be included in different campaigns that promote public hygiene and public health care

Therefore, North Korea insists on preventive care due to the lower cost and spirit of mutual cooperation. Unfortunately, it is often difficult to rely solely on preventive care, especially when the government needs to battle an unfamiliar or infectious disease. Furthermore, an overemphasis on preventive medicine creates an imbalance in the health care system. It is also difficult to expect that forcing citizens to participate in movements to promote public health care will have longterm effects.

Thirdly, North Korea has a "system of regional general doctors", which refers to a system in which authorized doctors take over the health care of the citizens in its entirety in a certain region (Choi Kim and Hwang 2006, 28). Usually, two to 10 doctors are responsible for around 4,000 inhabitants in urban regions and 3,000 in rural areas (Seung 1986,110-30). At first glance, such a system seems to be good, as certain medical personnel can be undisturbed in their observation of their patients and apply measures systematically. However, the health care system implemented by North Korea can also be very problematic, because the regional medical doctors have to manage not only the treatment and care of patients, but also health hygiene, preventive vaccinations, and regular health check-ups. Therefore, such systems can be very fragile, especially in times of epidemics.

Fourthly, North Korea also seeks to invest in the development of traditional medicine, called goryeouibak (Korean medicine), as well as Western medicine. "Korean medicine" is also called jeontonguibak (traditional medicine) or dong(yang)uihak (Eastern medicine). In each province, there is a hospital that specializes in traditional medicine, however, there are also many pharmacies that sell traditional medicine products. Korean medicine from North Korea is also known in South Korea, where the branch is known as hanbanguibak. In North Korea people are very proud of Korean medicine, which is known as an excellent form of preventive care. Korean medicine is thus mainly preventive, while Western medicine is mostly meant for treatment. Moreover, nowadays people in Korea are trying to use and develop both branches of medicine for health care (Choi, Kim and Hwang 2006, 30).

Fifthly, in North Korea health care services are conducted with the help of citizens. These are various movements (campaigns) carried out by the North Korean 
government under the banner of collective health care services. One of the main movements is the "antipollution campaign", which involves hunting animals and other pests that carry contagious diseases, thus preventing pollution. We cannot say that the intentions of such a campaign are bad, but it is difficult to know whether the participation of the citizens is voluntary or mandatory on the orders of the authorities. The North Korean health care system appears to be well intentioned and well designed, but there is often a lack of health care facilities and medical personnel. It is also criticized for giving precedence to state security rather than health care (Gim Yeong-gyo 2020).

\section{North Korea's Fight with Infectious Diseases}

Based on the above-mentioned health care policy, North Korea adopted the Infectious Disease Prevention Act in 1997 as the only law to prevent and contain epidemics. It is composed of five chapters and 45 articles. The law aims to protect the lives and health of the citizens of North Korea, with the main focus on detecting the causes of infectious diseases and isolating infected cases (Hwang 2020, 23). The law covers almost everything that needs to be done to prevent the spread of infectious diseases, which entails: the detection and isolation of sources of infectious diseases, testing, reporting of sources and suspicions of infectious diseases, organization of an urgent body to prevent the epidemic, disinfection of objects, a temporary suspension of operations for areas where infected patients have been detected, isolation and transportation of patients, determination of residences of infected persons, treatment of patients, and the processes of health examinations after patients are discharged from the hospital. Important steps to prevent the spread of the disease are thus regulated by law.

The most important part of the law is the 8th article. According to this, North Korea would have to cooperate with the international community in the case of an epidemic, i.e. it would have to support exchanges and cooperation with other countries and international organizations in the field of infectious disease prevention (Hwang 2020, 23). This means that North Korea is aware of the dangers of the spread of such diseases and considers international cooperation to be essential in the search for alternative solutions.

In addition to passing laws, North Korea also sought to increase the number of health care workers trained to contain infectious diseases. For example, there are specially trained doctors who manage protective measures and do preventive work against the spread of such diseases. A Department of Hygienic Nursing has been created in Pyongyang Medical College and in 11 provincial medical universities 
across the country. After completing the five-year program, students become hygienists. In 2011, 2,840 students obtained this title. In accordance with the system of a regional general doctor, a hygienist was also appointed in each region.

Since 1990, the country has had a developed system of "health care assistant-doctors" who specialize in detecting infectious diseases and making a diagnosis. If someone wants to become a health care assistant-doctor, he/she must attend a higher school of public health. Currently, there are reportedly about 40-50,000 health care assistants in North Korea (Hwang 2020, 24).

North Korea also conducts research work on infectious diseases caused by pathogenic microorganisms at the Institute of Medical Biology and the Institute of Microbiological Research, which are part of the Academy of Health Sciences of the Ministry of Health. Recent data shows that the Institute of Medical Biology mainly conducts research on the hepatitis virus (ibid., 28).

In North Korea, infectious disease containment is organized like other systems of administration. The North Korean Workers' Party is at the centre of central administration, while the Ministry of Health oversees sanitation and prevention policies (Cho Sungeun 2020,63). Nevertheless, it is difficult for most residents to obtain an accurate diagnosis or expert medical advice, so they self- diagnose and purchase medicines from the market, making it difficult to control a disease outbreak in its early stages (Hwang 2020,28). When an infectious disease emerges in North Korea, preventive and control measures usually focus on the predicted regions of disease outbreak. At the time of the SARS epidemic in 2003, the government sanitary inspectorate created the National Board for urgent epidemic prevention, created checkpoints, and monitored conditions throughout the country. When the Ebola virus broke out in 2014, they set up a sanitary station in the vicinity of the Daedong River and strengthened inspections at airports and seaports, thoroughly checking anyone attempting to enter North Korea (ibid.). To prevent the spread of infectious diseases through public transportation, they established a sanitary station responsible for the hygienic care of railways under the jurisdiction of the (North) Korean State Railway (Baek 2007,21). When an acute infectious disease such as measles, typhoid or paratyphoid breaks out, residents are not allowed to move between regions. They can only enter another region if they have a "sanitary certificate", which is issued at checkpoints in each residential district to those who do not display symptoms of infection (Hwang 2020,28). If infectious diseases appear abroad, the people desiring to enter the country must be quarantined or they will be deported. Thus they prevent the spread of infectious diseases within the country. During the SARS outbreak in 2003, they halted all overseas flights and completely sealed off all sea routes. This was the most extensive border 
closure measure in the world. At the time, anyone entering North Korea had to go into quarantine for 10 days, while ship crews from foreign ports had to anchor $30 \mathrm{~km}$ from the port and endure quarantine there.

The North Korean measures against infectious diseases are preventive and very strict, which is positive, but one would not expect the reason for this to be hidden in the outdated health care system. However, because health facilities are so outdated, an epidemic could be a hopeless tragedy, and this is the reason why North Korea focuses on preventive medicine.

\section{North Korea's Fight with COVID-19}

When COVID-19 spread rapidly in China in early 2020, North Korea created the "temporary board for the advice of citizens on health care" and established a national system for urgent prevention of epidemics (Hwang 2020, 21).

Each province organized severe restrictions, while stricter prevention controls were implemented in places where contact with the outside world was possible, such as borders, seaports, and airports. Thus North Korea reacted quickly and acted immediately after closing the border on January 22, 2020, in an attempt to show that it had the best system of governance. On January 28, when the National Disease Prevention System was established, the customs office in Dandong was closed; two days later, they also halted the function of the Inter-Korean Relations Office. The next day, rail and air traffic between North Korea and China was suspended. Foreigners coming to North Korea had to go into quarantine (Rodong Sinmun 2020), and the quarantine period was extended from 21 to 30 and later to 40 days. In addition, guidelines for the disinfection of goods coming from abroad and regulations for border and preventive controls were published in February 2020, and their consistent compliance was ordered (Cho Sungeun 2020, 71). For air travel, health and preventive controls were conducted on the plane rather than at sanitary-inspection checkpoints in the country (Rodong Sinmun 2020b). According to the guidelines, the authorities inspected and disinfected goods coming from abroad, these were then isolated for 10 days and only then distributed (Bak Myeong-su 2020). They prevented the spread of infectious disease by first restricting anything that could cause the spread of infection, and thus claimed that there were no cases of infection with COVID-19 in North Korea. Still, it is hard to know exactly what the current conditions are in that country.

If we look at recent responses of North Korea to COVID-19, we can see several irrational behaviours. While the various reports might appear to be nonsensical, they can be considered as following an inner logic of DPRK governance. 
For example, when the economic crisis began due to COVID-19, which caused the exchange rate to fall, Kim Jong-un ordered the execution of a leading money trader, blaming him for the sharp drop in the exchange rate in Pyongyang, and because seawater might be infected with the COVID-19 virus, he prevented fishermen from fishing and also stopped the production of salt (Song 2020). In addition, North Korean hackers attempted to penetrate the systems of South Korean pharmaceutical companies researching the treatment of COVID-19 and developing vaccines. They also attempted to break into the systems of American and British pharmaceutical companies (Nyus1 2020). Japanese media also reported that North Korea has imported Russian vaccines and begun the process of vaccination (Bak and Gim 2020). Considered all together, we can assess that North Korea is struggling with numerous issues due to COVID-19 and is striving to find solutions as best as possible. The impact of COVID-19 is thus so great that even North Korea cannot overlook it.

\section{The Impact of COVID-19 on North Korea}

\section{The Impact on the Economy}

The issues raced by the North Korean economy are nothing new, and therefore it would be difficult to argue that they arose because of COVID-19. Nam Seong-uk describes the current conditions as a "double blow", meaning that North Korea's issues have more than one cause, at least two (Nam Seong-uk 2020, 25). North Korea first struggled with economic problems due to economic sanctions implemented by the United Nations Security Council, while these problems deepened due to COVID-19 in 2020.

In the last decade North Korea has conducted about six nuclear tests and also tested an intercontinental ballistic missile (ICBM) that threatens not only neighbouring countries, but the entire world. Therefore, the United Nations Security Council has decided that it will prevent North Korea from developing nuclear weapons through economic sanctions. This is a reasonable decision, as a complete ban on trade with North Korea would halt the flow of goods and money and hinder the development of weapons from an economic perspective. Additionally, it would attempt to prevent North Korea from profiting from foreign countries through the sale of weapons of mass destruction. The development and production of nuclear weapons are made difficult without an income. Therefore, when living conditions became difficult for its citizens, the government of North Korea decided to stop the development of nuclear weapons and ask the international community for aid. 
After the United Nations published the "Resolution of the Security Council of the UN 2270" on the restrictive measures against North Korea in 2016, the North Korean economy took a massive step backwards. There was a complete ban on the inflow of the American dollars to North Korea, while the import of goods related to oil and essential for industrial development was limited to small quantities. These restrictions on the inflow of money and oil had a significant negative effect on the economy of North Korea. The level of economic growth was $-3.5 \%$ in 2017, $-4.1 \%$ in 2018 , and was expected to be $-6 \%$ in 2020 . Exports were greatly reduced, and while in 2017 these stood at 1.77 billion dollars, in 2018 this fell to only 240 million, and there seems to be no end to these conditions. The restrictions also ban overseas workers from sending money back home, further collapsing the North Korean economy (Cho Young-Ki 2020, 184). In 2017, North Korea attempted to overcome the economic crisis created by the official sanctions and bring about an economic turnaround through various construction projects, but the desired effects failed to materialize. Even more, the entire mining, manufacturing and heavy chemical industries declined even further and have still not recovered.

After the United Nations Security Council economic sanctions, North Korea became dependent on China. Since 2015 China has been the country's largest business partner, although North Korea also trades with others, including India, Pakistan, Angola, Burkina Faso, Taiwan, Saudi-Arabia, and Brazil. However, in 2016 the economic sanctions of the United Nations Security Council changed things very rapidly. Whereas India had previously imported goods worth $\$ 100$ million from North Korea, this amount dropped by $95 \%$ to only $\$ 4.84$ million. Likewise, Pakistan imported North Korean goods worth $\$ 7.3$ million in 2018 , which was $85 \%$ less than a year earlier, while Taiwan and Mexico ceased to import North Korean goods. Although the volume of trade with China has not increased, the degree of dependence has, due to the fall in trade with other countries. Based on the report published by the Korean Association for International Trade, the Chinese share of North Korean total foreign trade increased from 17.3\% in 2001 to 91.8\% in 2019 (Nam Seong-uk 2020, 30). The current economic dependence of North Korea on China is thus immense. Even though China has decided to participate in the sanctions imposed on North Korea, it cannot seem to fully comply if it wants to maintain the "market" economy created by smugglers, and therefore continues to export goods into North Korea (Go 2020, 36).

Before the UN Security Council economic sanctions, it seemed as if the North Korean economy would take off. North Korea created the jangmadang economy (North Korean marketplaces), it increased profits by increasing exports to China, and it improved its economy by sending workers to China to generate money in foreign currencies. They assumed that such economic policies would be 
successful (Go 2020, 33). However, when the economic sanctions became official, trade routes to China were cut and there were fewer opportunities to work abroad. Additionally, in early 2020 the border between North Korea and China was completely closed due to COVID-19, causing exports of goods to China to drop by $96 \%$ and imports to drop by $90 \%$. As a result, economic growth sustained by trade with China came to a complete halt due to COVID-19.

The economic shock was carried over to the inhabitants of North Korea. The borders were closed in January 2020 and prices for goods began to fluctuate as early as February. The North Korean government acted quickly. First of all, it announced that sellers could not ask for more than 5,000 North Korean won for a kilogram of rice, and that anyone who violated this rule would be severely punished. Nevertheless, in mid-February the residents of some regions of North Hamgyong Province had to pay more than 10,000 North Korean won for a kilogram of rice, meaning that the price had doubled (Kim Ji Eun 2020c, 97). According to sources from the North Hamgyong Province, there was a significant decrease in the number of people at the jangmadangu (North Korean marketplaces) in March 2020 due to COVID-19, although these are usually full of people depending on the weather (ibid., 98). The North Korean economy, which had been heavily dependent on China since 2010, was devastated by the economic sanctions imposed by the United Nations Security Council and then had to go through an even bigger crisis due to COVID-19 before it could recover from the first.

\section{Impact on Society}

COVID-19 affected not only the economy of North Korea but also its society. North Korea closed its borders and actively encouraged its citizens to wear masks to prevent the entry and spread of COVID-19 from abroad. Despite this, the citizens allegedly did not pay much attention to mask-wearing (Kim Ji Eun 2020c, 95). As mentioned earlier, the prices of food, such as rice, increased rapidly, but the prices of masks surprisingly remained the same due to the lack of interest from the public. The reason for this is the lack of information provided by the North Korean government on the number of cases of infection, despite actively educating people on preventive care. Therefore, the citizens did not have accurate information about the dangers of COVID-19 and believed the disease was not very dangerous. There was a lack of information on COVID-19 leading to a spread of unreasonable opinions among the population, such as that the drug methamphetamine could be successfully used as a cure for COVID-19 (ibid., 96). North Korea's educational system also suffered greatly from COVID-19, with the start of 
the school year being pushed back by two months. Even South Korea had problems in carrying out its education in 2020 due to COVID-19, not only in elementary and middle schools, but also in universities. Classes were often cancelled, and most university lectures were held online, leading to some schools being sued for tuition refunds. Many problems occurred when, due to the adverse circumstances, the date of the final exams for high-school and middle-school students had to be postponed (Sin 2020). North Korea could not avoid similar problems. The new semester there usually starts on April 1, but students in 2020 did not start classes until June 1 after the start date was postponed three times (Jo 2020). The early semester break was announced on April 1, just a month after the semester started. In addition, students from rural areas living in dormitories in Pyongyang had to return to their places of origin immediately by order of the education authorities. It could be said that achieving a regular education was almost impossible during this time (Kim Ji Eun 2020a, 97). Although North Korea made an official statement that there were no confirmed cases of COVID-19 infection, the education authorities adopted decisive measures. We can thus deduce that North Korea suffered from the consequences of COVID-19 in numerous areas, including education.

The second social problem that stands out is the increase in discontent among the citizens of North Korea, because the government needed to control people more strictly due to the "double blow". We must emphasize that such discontent has increased not only among the common people, but also among the upper class.

The saying "Are you the General Kim Jong-il?" has reportedly been heard a lot recently among the people of North Korea, it was also used in the South Korean television series Crash Landing on You (Sarangui bulsichak) (ibid. 2020b, 126). Behind this popular humorous expression is a criticism of the "highest dignitary (Kim Jong-il and Kim Jong-un)" who likes to pretend that he is well respected and something more. Ostensibly, this is how North Koreans expresses their dissatisfaction with the Communist Party, which constantly enforces coercive control and fails to provide the people with even the minimal requirements for survival (ibid., 127-28). It is not common to make jokes about the supreme leader, however, and thus the popularity of this rhetorical question indicates that life of North Koreans had become so difficult that the people decided to direct their dissatisfaction against the highest person in the land, Kim Jong-un.

Although Kim Jong-un stressed the "safety of the lives of the people of Pyongyang", it would seem as though these were just words to prevent the agitation of those living in the capital who are the main supporters of his party (Gim Myeong-seong 2020). Since the higher classes of North Korean society, such as 
Communist Party members, government officials, and soldiers, reside in Pyongyang, it has a special administration and enjoys certain benefits. However, due to the economic sanctions against North Korea and the outbreak of COVID-19, their lives were also made more difficult. During the outbreak of COVID-19, food was so scarce that even administrative workers of the ruling party could not procure it, prompting Kim Jong-un twice (in March and June 2020) to order that Pyongyang residents be provided with food, electricity and firewood. This measure was necessary because, as mentioned above, the consequences of increasing economic issues and long-term sanctions against North Korea and the closure of the borders due to COVID-19 were also felt by the residents of the capital, who began to complain because of psychological issues and discomfort. Pyongyang residents are the main supporters of the regime, so Kim Jong-un actively tried to reduce public discord and ensure social stability (Kim Hakil 2020).

The North Korean economy struggles with irreversible issues because of COVID-19, the consequences of which are felt not only by ordinary citizens but also by the central ruling class. COVID-19 is a huge blow to the entire society because it forced the restriction of economic activity and the halt of the educational process. Dissatisfaction is thus growing in all sections of society, and it is obvious that these conditions are also causing the policies of the North Korean regime to change.

\section{Impact on Politics}

In recent years, it has been difficult to say that the highest ruler of North Korea is its supreme leader Kim Jong-un because of the growing influence of Kim Yo-jong, the first deputy of the Workers' Party of Korea (WPK) and the younger sister of Kim Jong-un. She has also made frequent appearances on the political stage during the 2018 Pyongchang Olympics, acting as the voice of Kim Jong-un. With her arrival, the so-called "politics of brother and sister (or the rule of brother and sister)" began (Cho Young-Ki 2020, 180).

Since then, the two leaders have had good and bad political roles. Most notably, outwardly Kim Jong-un (with a moderate attitude) functions as a "good cop", while Kim Jo-jong functions as a "bad cop" (with a relentless attitude). They express different political messages.

When the COVID-19 pandemic began in 2020, the North Korean "double politics" became even more apparent. As noted above, North Korea could not avoid economic and social problems during the global crisis, and thus its leadership seems to have assessed that the system would be difficult to sustain with only the 
unilateral local and international policies and one-sided messages that they relied on in the past.

When North Korea tested the launch of two ballistic missiles on March 2, 2020, the Blue House (Cheongwadae, the executive office and official residence of the Republic of Korea's head of state) convened an emergency ministerial meeting and issued a statement: "We urge you to cease your behavior, it does not contribute to the relaxation of military tension on the Korean peninsula." This was an expected response from South Korea. Kim Jo-jong however, intensely criticized it. She said "I am surprised at the half-witted way of thinking of the Blue House." She then added, "It is similar to the unreasonable demands of the United States of America." She did not hold back on the use of insulting terms, such as "cowardly dogs" and "complete idiots" (Noh 2020). On the other hand, the day after her statements the Supreme Leader Kim Jong-un sent a letter offering support in the fight against COVID-19 to the South Korean President Moon Jae-in, which the latter replied to (Seong 2020).

At first glance, the actions of North Korea seem unreasonable, however, they are based on a carefully planned strategy (Cho Young-Ki 2020,182). We could say that these statements were pre-prepared on the orders of the North Korean double politics.

Kim Yo-jong made another decisive statement on June 4, 2020. It said that due to North Korean deserters who had fled to South Korea and are releasing balloons with leaflets, they will close the Gaesong industrial complex, the facilities South Korea built on Mount Geumgangsan, and the Inter-Korean liaison office. The facilities of this office were actually blown up and the beginning of the military action against South Korea was declared, causing great tension between the two Koreas (ibid.). Nevertheless, Kim Jong-un declared on June 24 that the country would hold off on the plan for military action. This was in complete contradiction to the statement of Kim Yo-jong in the same month, who once again embraced the role of the "bad cop" who increases tensions, while Kim Jong-un took the role of the "good cop" who eases them. Therefore, the prevailing opinion is that Kim Jo-jong is not simply an assistant to Kim Jong-un, but has a larger political role, and it is clear that she has an all-encompassing influence on politics, diplomacy and military affairs (Jeong and Bak 2020). "The brother-sister politics" of Kim Jong-un and Kim Yo-jong, which began in 2018, became even more evident and publicized due to the spread of COVID-19 in 2020. It would seem that they are trying to alleviate the economic and social crises caused by the spread of COVID-19 and the sanctions against North Korea by implementing a form of "joint rule". This may not be the best solution, but it could be seen as a way to avoid or 
divide responsibility. Even though Kim Jong-un is the official supreme leader of North Korea, he left military affairs to the head of the military administration Choe $\mathrm{Pu}$-il 최부일 and Ri Pyong-chol 리병철, the deputy chairman of the Central Committee of the North Korean worker's party, economic affairs were left to Pak Bong-Ju 박봉주, the deputy chairman of the State Affairs Panel and Prime Minister Kim Tok-Hun 김덕훈. He likely did this to avoid responsibility for the incoming economic and social distress and divided the pressures of citizens' complaints among several people (Kim Kwang Il 2020). Moreover, it seems that the statements made by Kim Yo-jung try to show an image of a strong North Korea, while those made by her brother, Kim Jong-un, aim to calm South Korea and the outside world. North Korea has therefore been emphasizing "the cooperation of the Korean community" since April 2020, insisting that issues on the Korean peninsula should be solved directly by South and North Korea alone, without relying on the interventions of the USA and other countries. South Korea should stop clinging to international opinions and respect the inter-Korean agreements and cooperate with North Korea's economy. The calm attitude of Kim Jong-un is thus understood as a message to the government of Moon Jae-in to ensure economic support so that North Korea can defeat the crisis caused by COVID-19 with the help of inter-Korean cooperation (Cho Young-Ki 2020, 183).

North Korea is making efforts to overcome its major economic and social problems, and puts on a political show to share the responsibility associated with the major challenges it already faces or will face. In 2020, the Rodong Sinmun newspaper revealed that North Korea was seriously studying the conditions and preparing political tactics and strengthening political projects to prevent the spread of COVID-19. However, the reports noted that it would never be able to defeat COVID-19 with politics and "political power" alone (Jang 2020, 6).

\section{The Cooperation between South and North Korea in the Post-COVID-19 Era}

Cho Han-bum $(2020,2)$ emphasized the "importance of cross-border cooperation" in combating the disease, noting that "COVID-19 is democratic". He used the words of the German sociologist Ulrich Beck, who said that "poverty is hierarchical, while smog is democratic". Cho Han-bum perceives COVID-19 as democratic because the related crisis affects all people equally and without exception. In this sense, COVID-19 might be even more "democratic" than smog, since smog occurs mostly in big cities where there is more pollution, while it was almost absent in rural areas with cleaner air. In contrast, COVID-19 does not know 
proportional dispersion. It thus goes without saying that a joint response and not isolation is important for victory against COVID-19, which has spread across all borders and affects all humanity. South Korea especially needs mutual cooperation with North Korea, the only country it borders. Some claim that inter-Korean cooperation means aid from a humanitarian point of view, and while this could be a start it should certainly not be the ultimate goal. All this should be perceived as a step towards mutual cooperation and living, not as one country helping another.

\section{Current Conditions in the Field of Medical Cooperation: The Focus on the Prevention of Infectious Diseases}

Until now, North Korea has relied on the technical and financial support of international organizations and South Korea when it came to the control of infectious diseases. When a new influenza (so-called swine flu) broke out in North Korea in November 2009, it asked the government of South Korea directly for assistance with medical treatment. Inter-Korean relations were not good at the time, yet South Korea helped. Even during the Ebola epidemic in 2014 and outbreak of MERS in 2015, there were exchanges in the field of health care; for example, at the request of North Korea, South Korea facilitated the installation of a thermal imaging camera in the entry office of Gaeseong Industrial Complex and collected data on preventive measures (Hwang 2020,32). If we are accurate, we could call this unilateral support rather than an exchange (or cooperation).

Support for North Korea in the health care sector began in 1997, and until 1999 this accounted for only 1-4\% of total humanitarian aid to North Korea. However, since 2000 the amount increased rapidly as health sector support also included infectious disease control, medicines, and medical equipment (Yeonseuiryowon 2015, 53). Health care support to North Korea in the field of infectious disease prevention can be divided into two parts. The first part is the prevention of autochthonous infectious diseases, while the second part is support to combat infectious diseases that come from abroad. Malaria is one of the autochthonous diseases, while foreign infectious diseases include swine flu, MERS, SARS and COVID-19.

Malaria first appeared in North Korea in 1999, with a report of 15,362 patients, in 2000 the number rose to 90,582, and in 2001 to 143,674 (WHO 2011, 233). When the number of patients increased rapidly in 1999, the WHO decided to help North Korea with the cooperation of South Korea. On March 8, 2000, the Korean government purchased 500,000 US dollars' worth of prevention and health care materials from the WHO (Tonglibu 2002, 169). In 2001, 
it increased the amount and received the support of 590,000 American dollars (ibid. 2003, 237). The amount of South Korean government support for the fight against malaria in North Korea continued to grow, reaching one billion Korean won in 2008 and 1.3 billion in 2009. This support enabled North Korea to manage the number of patients relatively well, with 16,989 in 2008 and 14,845 in 2009. However, when inter-Korean relations became colder South Korea ceased to support North Korea in the fight against malaria. The number of people infected by malaria increased to 16,760 in 2011 and 21,859 in 2012 (WHO 2019, 182). From this, it can be seen that the support of South Korea has been crucial in the prevention of malaria.

North Korea also received South Korean support in the fight against infectious diseases coming from abroad, and the effect of the support was even more evident in the fight against swine flu than against malaria. Swine flu first appeared in the USA in April 2009 and spread to 214 countries. At the time, WHO warned of the disease and declared a pandemic (Kim Eu Suk 2020), which North Korea was unable to escape. On December 9, 2009, the North Korean news agency KCNA officially reported that there were nine confirmed cases of swine flu in Sinuiju and Pyongyang (Bak Ji-hwan 2009). When the South Korean government received this news, it sent 400,000 doses of the drug Tamiflu and 100,000 doses of Relen$\mathrm{za}$, for a total of 500,000 doses (Kim Seung-wook 2009). North Korea revealed on January 19, 2010 how they used the medication received from South Korea. They distributed 380,000 doses to all cities and provinces, while storing 120,000 doses in the State Committee for Emergency and Disaster Management (SCEDM) (DailyNK 2010).

During the outbreaks of MERS and the Ebola virus brought to North Korea from abroad, the South Korean government procured and gave away equipment for preventive measures, such as thermographic cameras. We must emphasize that North Korea requested aid through the Board for the Management of the Kaesong industrial complex (Kim Hojun 2015). This is evidence that North Korea recognized the threat of infectious diseases spreading from abroad and wanted to act quickly by encouraging help with preventive care from South Korea.

Since COVID-19 is also a foreign infectious disease, North Korea strived to prevent the spread on a national level and therefore closed its borders with China at the beginning of the outbreak. However, it did not officially ask for South Korean support when it came to preventive care, as previously done to combat swine flu, Ebola or MERS. Nevertheless, the South Korean government issued a permit for the support of projects by private humanitarian organizations to help North Korea with preventive care in the fight against COVID-19, without disclosing their 
names or plans. Although there was no official support at the government level, the private sector was allowed to help North Korea, and there were reports that at least 300 million Korean won' worth of relief supplies were procured by various organizations.

The inter-Korean medical cooperation has not been reciprocal, as only South Korea has provided humanitarian aid to North Korea. This mainly happened in cases where North Korea needed or asked for aid, and in these cases aid was limited to urgent cases that made the end results clear, with relatively shortterm projects.

Relations and political factors between the two Koreas also influenced health care and medical cooperation. However, since health care and medical cooperation are directly related to the lives of ordinary people, it should be carried out regardless of the political circumstances, and most importantly without interruptions.

\section{The Plan for Inter-Korean Cooperation in the Field of Health Care}

The agreement on the mutual statement from Pyongyang issued by the inter-Korean leadership on September 19, 2018 included a written record that South and North Korea should jointly take necessary measures to prevent the spread of infectious diseases and strengthen cooperation in the field of preventive care and health care. This record on inter-Korean health care cooperation in the Agreement on the Pyongyang Mutual Declaration Agreement shows that the Koreas should make joint efforts in this field because in this way they could protect people's lives and reduce socio-economic problems in advance (Hwang 2020, 31-32).

However, for inter-Korean cooperation in health care to be effective and undisturbed, a more concrete plan is needed, not just an aimless project.

Firstly, humanitarian aid through private organizations should continue. As mentioned earlier, North Korea did not officially request aid from its southern neighbours during the COVID-19 outbreak, but only accepted aid from private organizations. If we wish to build trust, we must not stop helping through private and international organizations. The channels of private organizations should always remain open, because they work independently of the government and are not influenced by politics.

Secondly, awareness of inter-Korean cooperation in the field of health care and medicine should be raised in South Korea. Such cooperation should be taken as 
a starting point for the "Korean Peninsula Living Communities" or "Korean Peninsula Health care Community" currently under discussion. It should be stressed that cooperation in the health care and medical fields could ensure a healthy life together for the residents of both South and North, therefore they should be actively informed about it (Lee Wootae 2020, 105). If we ignore the health care crisis in North Korea then we should not be surprised if it also endangers South Korea, and it must be recognised that in the case of infectious diseases the whole peninsula is at risk. We must also not overlook the fact that if the two Koreas were to unite, there would be even greater costs if we neglect cooperation in the field of health care. Closing the gap in health care systems between the South and North is one of the ways to prevent conflicts after unification. The fact that health care cooperation has a direct impact on reducing the cost of reunification should be actively promoted, and ties of empathy should be developed in both Korean societies.

Thirdly, there should be a beginning of low-level practical cooperation in accordance with current United Nations Security Council sanctions against North Korea. Joint academic conferences in common fields, the exchange of health care and medical technologies, and preventive cooperation would be possible. An infectious disease control network, and thus information sharing, should be established based on the existing inter-Korean agreement (Hwang 2020, 33). From a long-term viewpoint there should be an exchange of information not only on infectious diseases, but also from the general health care and medical fields, as well as from the fields of climate, environment, forestry, and so on, thus expanding cooperation.

For more effective and long-term cooperation in the field of health care and medicine, a special organization would have to be formed, such as the inter-Korean board for health care and medical cooperation. This could be considered as a fourth step. Such an organization would not only allow for regular and sustained health care cooperation, but also a joint response in the event of an infectious disease outbreak. In addition, a guidebook on health care could be issued, and perhaps the organization could even be used to conduct joint research.

We must not view cooperation between the Koreas in a narrow sense. Such cooperation is not only directly related to the lives of the inhabitants of both countries, but is also the foundation of cooperation in other areas, such as climate, the environment and forestry. 


\section{References}

Asmolv, Konstantin V. 2020. “The Korean States' Policy on Fighting the Coronavirus." Far Eatern Affairs 48 (3): 1-14.

Baek, Do-myeong 백도명. 2007. Bukan wisaengbangyeokwaldong chegye guchugui banghyang suribeul wiban giban yeongu 북한 위생방역활동 체계 구축의 방 향 수립을 위한 기반 연구 (Research on Guidelines for the Establishment of the Sanitary and Preventive Care System in North Korea). Sejong: Bogeonbokjibu 보건복지부 (Ministry of Health and Welfare).

Bak, Hyeongjun 박형준, and Gim Yunjong 김윤종. 2020. “Bukdo baeksin jeopjong sijak, reosiaseo gumae... gimjeongeuneun jeopjong anhana 北도 백신 접종 시작, 러시아서 구매... 김정은은 접종 안하나 (North Korae's Vaccination Purchased from Russia Started ... Doesn't Kim Jong-un Get Vaccinated?).” Dongailbo 동아일 보, December 15, 2020. https://www.donga.com/ news/Inter/article/all/20201215/104459469/1.

Bak, Ji-hwan 박지환. 2009. "Buk, sinjongpeullu balsaeng gongsik hwagin 北, 신 종플루 발생 공식 확인 (North Korea Confirms H1N1 Outbreak Officially).” Nocutnews, December 9, 2009.

Bak, Myeong-su 박명수. 2020. "Sinhyeong koronabiruseugamyeomjeungeul cheoljeohi makja 신형코로나비루스감염증을 철저히 막자 (Let’s Stop COVID-19 Thoroughly).” Rodong Sinmun, January 26, 2020. http://uriminzokkiri. com/index.php?ptype $=$ cgisas\&mtype $=$ view $\&$ no $=1186286$.

BBC. 2020. "COVID-19 Vaccine: First Person Receives Pfizer Jab in UK." $B B C$, December 8, 2020. https://www.bbc.com/news/uk-55227325.

Cho, Han-bum 조한범. 2020. "Korona 19wa nambuk bogeonanbogongdongche 코로나 19와 남북 보건안보공동체 (Corona 19 and the South-North Korean Health and Security Community).” KINU (Korea Institute for National Unification), March 24, 2020. https://www.kinu.or.kr/www/jsp/prg/api/dlV. jsp? menuIdx=351\&category $=53 \&$ thisPage $=1 \&$ searchField $=\&$ search Tex$\mathrm{t}=$ \&biblioId $=1532089$.

Cho, Sungeun 조성은. 2020. "Bukanui bangyeokchegyeui korona19 daeeung 북한의 방역체계의 코로나19 대응 (North Korea's Quarantine Sysyem against COVID-19)." In Gamyeombyeong gongdongdaeeungeul wiban nambugindohyeomnyeok 감염병 공동대응을 위한 남북인도협력 (Humanitarian Cooperation between the Two Koreas to Counter Infectious Diseases), edited by Indohyeomnyeongnyeongusil 인도협력연구실, 45-76. Seoul: Tongillyeonguwon 통일연구원 (Korea Institute for National Unification).

Cho, Young-Ki 조영기. 2020. "Korona19 ihu tongiljihyangui daebukjeongchaek 코로나19 이후 통일지향의 대북정책 (South Korea's Unification-Oriented Policy toward North Korea after COVID-19).” Seonjinhwa jeongchaeksirijeu 선진화 정책시리즈 2: 172-201. 
Choi, Young-In 최영인, Kim Soo-Youn 김수연, and Hwang Sang-Ik 황상익. 2006. "Jeongseongundongi bukan bogeonuiryoe michin yeonghyang 정성운 동이 북한 보건의료에 미친 영향 (The Influence of the Devotion Movement on the Health Care in North Korea)." Uibaksa 의 학사 28: 23-48.

Daily NK. 2010. "Buk sinjongpeullu chiryoje 38manmyeongbun bunbae 北 신종 플루 치료제 38만명분 분배 (The North Korean Authorities Announced that They had Given Out Drugs for the Swine Flu to 380,000 People).” Daily NK, January 19,2010. https://www.dailynk.com/北-신종플루-치료제-38만 명분-분배/.

Gim, Myeong-seong 김명성. 2020. "Pyeongyangsimin saenghwal bojang eongeupan gimjeongeun... wae? 평양시민 생활 보장 언급한 김정 은... 왜? (Kim Jong-un Mentions the Guarantee of Living Quality in Pyongyang Why?).” Joseonilbo 조선일보, June 9, 2020. https://news. naver.com $/ \mathrm{main} / \mathrm{read} . \mathrm{nhn}$ ? $\operatorname{mode}=\mathrm{LSD} \& \mathrm{mid}=\mathrm{sec} \& \operatorname{sid} 1=100 \&$ oid $=023 \&$ aid $=0003537466$.

Gim, Yeong-gyo 김영교. 2020. "Bukanui nakudoen uiryo siseol, haek useon jeongchaek tat 북한의 낙후된 의료 시설, 핵 우선 정책 탓 (North Korea's Medical Lag Due to Nuclear-First Policy).” VOA, March 19, 2020. https:// www.voakorea.com/korea/korea-politics/pyongyang-hospital.

Go, Myong-hyun 고명현. 2020. “Jejaewa koronae hwicheongineun bukjunggyeonghyeop 제재와 코로나에 휘청이는 북중경협 (The Difficulties of Economic Cooperation between North Korea and China by UN Sanctions and COVID-19)." Bukan 북한 580: 32-39.

Hwang, Nami 황나미. 2020. "Bukcheugui gamnyeombyeong daeeungsiltaewa nambukyeomnyeok 북측의 감염병 대응실태와 남북협력 (North Korean's Response to Infectious Diseases and Inter-Korean Cooperation)." KDI Bukangyeongjeribyu KDI북한경제리뷰 2: 21-34.

Jang, Seul-Gi 장슬기. 2020. "Gamyeombyeongeul jeongchiro chiryoharyeoneun bukan 감염병을 정치로 치료하려는 북한 (North Korea Trying to Cure Infectious Diseases through Politics).” Bukan 북한 580: 1-6.

Jeong, Binna 정빛나, and Bak Suyun 박수윤. 2020. "Gimyeojeong, bukan 2inja jiwi gwasi 김여정, 북한 2인자 지위 과시 (Kim Yo-jong Shows off North Korea Number Two).” Midas, March 5, 2020. http://www.yonhapmidas. co.kr/article/200406170726_467408.

Jeong, Yong-su 정용수. 2020. "Gimjeongeun 'korona gwaminbaneung' ibeonen... hyujeonseon bongswaejangbyeok ganghwa 김정은 '코로나 과민반응' 이번 엔... 휴전선 봉쇄장벽 강화 ('Corona Hypersensitivity'by Kim Jong-un Reinforcement of the Military Demarcation Line)." JoongAng Ilbo, November 29, 2020. https://news.joins.com/article/23932576. 
JHU CSSE (COVID-19 Dashboard by the Center for Systems Science and Engineering at Johns Hopkins University). 2020. "Global Cases Global Deaths.” Accessed December 12, 2020. https://www.arcgis.com/apps/opsdashboard/ index.html\#/bda7594740fd40299423467b48e9ecf6.

Jo, Seong-won 조성원. 2020. "Buk, du dal mane gaehak... hwasang gaehaksik, adidaseu maseukeu deungjang 北, 두 달 만에 개학... 화상 개학식, 아디다 스 마스크 등장 (North Korea Postpones School Openings by Two Months ... Screen School Opening Ceremony and Adidas Masks Appeared)." SBS, June 7, 2020. https://news.naver.com/main/read.nhn?mode=LSD\&mid=sec \&sid1=100\&oid=055\&aid=0000819716.

$\mathrm{Kim}, \mathrm{Eu}$ Suk 김의석. 2020. "Kkeunimeomneun baireoseuwaui jeonjaeng, 21segi baireoseu chongmangna 끊임없는 바이러스와의 전쟁, 21세기 바 이러스 총망라 (The Constant War against Viruses, Everything about the 21st-century Viruses)." SNUH (Seoul National University Hospital). Accessed December, 12, 2020. https://www.snubh.org/service/info/com/view. do?BNO=381\&Board_ID=B004\&RNUM=1.

Kim, Hakil 김학일. 2020. "Buk, pyeongyangsimin saenghwaranjeonge anganhim... minsim dongyo chadan naseonna 北, 평양시민 생활안정에 안간 힘... 민심 동요 차단 나섰나 (North Korean Authorities Struggle to Stabilize Life in Pyongyang. Do they Appease Public Sentiment?).” Nocutnerws, June 2, 2020. https://news.naver.com/main/read.nhn?mode=LSD\&mid=sec \&sid1=100\&oid=079\&aid=0003379218.

Kim, Hojun 김호준. 2015. "Buk, gaeseonggongdan mereuseu geomyeokjangbi namcheuge jiwon yocheong 北, 개성공단 메르스 검역장비 南측에 지원 요청 (North Korea Requests South Korea to Support MERS Quarantine Equipment at the Kaesong Industrial Complex)." Yonhapnews, June 4, 2015. https://www.yna.co.kr/view/AKR20150604064500043?input $=1195 \mathrm{~m}$.

Kim,Ji Eun 김지은.2020a. "Bukan sahoee deuridakchin korona19ui pajang 북한 사회에 들이닥친 코로나19의 파장 (COVID-19's Impact on North Korean Society).” Bukan 북한 584: 94-103.

2020b. "Korona satae janggihwae juminbulman gajung 코로나 사태 장 기화에 주민불만 가중 (Increasing Dissatisfaction with North Koreans due to Prolonged COVID-19)." Bukan 북한 583: 126-33.

2020c. "Sinjong korona pokpunge hwimallin bukan 신종 코로나 폭풍 에 휘말린 북한 (North Korea Captured by COVID-19 Storm).” Bukan 북 한 580: 93-99.

Kim, Kwang Il 김광일. 2020. "Gimjeongeun gimyeojeong nammae chaegim hoepi gongdongjeongchi 김정은 김여정 남매 책임 회피 공동정치 (Kim Jong-un and Yo-jong, Join-Ruling for Avoidance of Responsibility).” Joseonilbo 조선일보, August 21, 2020. https://www.chosun.com/site/ 
data/html_dir/2020/08/21/2020082103486.html?utm_source=naver\&utm_ medium=original\&utm_campaign=news.

Kim, Seung-wook 김승욱. 2009. "Buge sinjongpeullu chiryoje 50manmyeongbun jeondal 北에 신종플루 치료제 50만명분 전달 (Delivered H1N1 Treatment for 500,000 People to North Korea).” Yonhapnewws, December 18, 2009. https://news.naver.com/main/read.nhn?mode=LSD\&mid=sec\&sid1= 100\&oid=001\&aid $=0003031945$.

Lee, Seong -hyon 이성현. 2020. "Bukan korona hyeonhwange daehan jungguk eonnonui bodo 북한 코로나 현황에 대한 중국 언론의 보도 (Chinese Media Reports on the Current Situation of COVID-19 in North Korea)." Institute of North Korea Studies, June, 22, 2020. http://nkorea.or.kr/board/index. html?id=focus\&no=95.

Lee, Wootae 이우태. 2020. "Yangjahyeomnyeogeul tonghan gamyeombyeong hwaksan bangjiwa daeeung 양자협력을 통한 감염병 확산 방지와 대응 (Preventing the Spread of Infectious Diseases through Mutual Cooperation)." In Gamyeombyeong gongdongdaeeungeul wihan nambugindohyeomnyeok 감염병 공동대응을 위한 남북인도협력 (Humanitarian Cooperation between the Two Koreas to Counter Infectious Diseases), edited by Indohyeomnyeongnyeongusil 인도협력연구실,77-120. Seoul: Tongillyeonguwon 통일 연구원 (Korea Institute for National Unification).

Maeil Business Nerwspaper. 2020. “Bukan, 'korona hwakjinja 0' dwijibeun ganggyeonghwae 'balkkeun'... gimyeojeong naseo 북한, '코로나 확진자 0’ 뒤집 은 강경화에 '발근'... 김여정 나서 (Kim Yo-jong is Angry at Kang who Opposed the Saying that there are No Coronavirus Confirmed Cases in North Korea)." Maeil Business Nerwspaper, December 9, 2020. https://www. mk.co.kr/news/politics/view/2020/12/1263555/.

Mo, Chun Heung 모춘흥, and Chung Byung Hwa 정 병화. 2019. "Bukangwaui gongsaeng, geu (bul)ganeungseong: singnyangmunjewa bogeonuiryo siltaereul jungsimeuro 북한과의 공생, 그 (불)가능성: 식량문제와 보건의료 실 태를 중심으로 (Conviviality of Two-Koreas and Its (Im)Possibility: With a Focus on Food Problem and Health Care Conditions)." Hyeondaesahoerwadamunhwa 현 대사회와다문화 9 (1): 133-62.

Nam, Seong-uk 남성욱. 2020. "Bukangyeongjeui ijunggo, daebukjejaewa sinjongkorona 북한경제의 이중고, 대북제재와 신종코로나 (Two Difficulties of North Korea's Economy, Sanctions and COVID-19).” Bukan 북한 579: 24-33.

Nam, Sung-wook 남성욱. 2020. "Koronabaireoseue tteolgo inneun bukan 코 로나바이러스에 떨고 있는 북한 (North Korea Trembling from Coronavirus)." JoongangilboPlus, February 17, 2020. https://jmagazine.joins.com/ monthly/view/329186. 
Noh, Minho 노민호. 2020. “Gimyeoncheol, buk gimyeojeong jeoneunghan cheongwadae damhwaedo sanghojonjung pillyo 김연철, 북 김여정 저능한 청와대 담화에도 상호존중 필요 (South Korea's Minister of Unification Said that even though Kim Yo-jong Said that The Blue House is Stupid, We Need to Respect Them).” Nyuseupim 뉴스핌, March 4, 2020. http://www. newspim.com/news/view/20200304001155.

Nyus1 뉴스1. 2020. “Jeyakoesa haekingkkaji son ppeonneun bukan... korona19 sanghwang eotteokillae? 제약회사 해킹까지 손 뻗는 북한... 코로나19 상 황 어떻길래? (Attempt to Hack North Korean Pharmaceutical Companies ... How is the Situation with COVID-19 in North Korea?).” Dongailbo 동 아일보, December 3, 2020. https://www.donga.com/news/Politics/article/ all/20201203/104269956/1.

Park, Soo-Yun 박수윤. 2020. "Bukan, sarangui bulsichak ingie balkkeun...uri gonghwaguk heoltteudeo 북한, 사랑의 불시착 인기에 발끈...우리 공화국 헐 뜯어 (North Korean Authorities are Angry at the Popularity of K-Drama, Crash Landing on You)."Yonhapnews, March 4,2020. https://www.yna.co.kr/ view/AKR20200304042500504?input $=1195 \mathrm{~m}$.

Rodong Sinmun 로동신문. 2020a. "Sinhyeong koronabiruseugamyeomjeungeul makgi wihan saeobeul gangdonopge jeongaehada 신형코로나비루스감염증 을 막기 위한 사업을 강도높게 전 개하다 (Intensive Launch of Campaign to Prevent COVID-19)." Rodong Sinmun, February 1, 2020. http://www. uriminzokkiri.com/index.php?ptype $=$ cgisas\&mtype $=v i e w \& n o=1186586$.

. 2020b. "Gwanmunchosoreul jikyeoseon nopeun chaegimgameul ango, pyeongyang hanggongyeok suip-pumgeomsageomyeokbunso geomyeogil gundeul 관문초소를 지켜선 높은 책임감을 안고, 평양항공역 수입품검 사검역분소 검역일군들 (Quarantine Officers at the Import Goods Inspection Office of Pyongyang Airport Station Working with High Responsibility).” Rodong Sinmun, February 2, 2020.

Seong, Yeon-cheol 성 연철. 2020. "Gimjeongeun chinseo korona19 geukbok eungwon 김정은 친서 코로나19 극복 응원 (Kim Jong-un' Letter: Support for Overcoming COVID-19)." Hangyeore 한겨레, March 5, 2020. http://www. hani.co.kr/arti/politics/bluehouse/931291.html.

Seung, Chang-ho 승창호. 1986. Inminbogeonsaeopgyeongheom 인민보건사업 경 험 (Experience of People's Health Business in North Korea). Pyongyang: Sahoegwahakchulpansa 사회 과학출판사.

Sin, Yeong-gyeong 신영경. 2020. "Ollain gaehak, wongyeoksueop, deungnokgeum banhwan sosong... koronaga hwipsseun 2020nyeon gyoyukgye 온라 인 개학, 원격수업, 등록금 반환 소송... 코로나가 휩쓴 2020년 교육계 (Korea's Education in 2020 Changed by COVID-19: Online School, the 
Lawsuit for Tuition Refunds)." Nerwdaily, December 24, 2020. http://www. newdaily.co.kr/site/data/html/2020/12/23/2020122300187.html.

Song, Hye-jin 송혜진. 2020. "Gimjeongeun korona hiseuteri... geomul hwanjeonsang cheohyeong, eoeop geumji 김정은 코로나 히스테리... 거 물 환전상 처형, 어업 금지 (Kim Jong-un's Corona Hysteria ... Execution of Big Money Changers, Fishing Ban).” Joseonilbo 조선일보, November 29, 2020. https://www.chosun.com/politics/2020/11/27/ LMIZ5KQU2ZB5VHOTQGHGH2ENLE/.

Tongilbu 통일부. 2002. 2002nyeon tongilbaekseo 2002년 통일백서 (Unification White Paper 2002). Seoul: Tongilbu 통일부 (Ministry of Unification).

2003.2003nyeon tongilbaekseo 2003년 통일 백서 (Unification White Paper 2003). Seoul: Tongilbu 통일부 (Ministry of Unification).

WHO. 2011. World Malaria Report 2011. Geneva: WHO.

WHO. 2019. World Malaria Report 2019. Geneva: WHO.

Yeonseuiryowon 연세의료원. 2015. Bukan jilbyeongtongje grwallichegye guchukbangan 북한 질병통제 관리체계 구축방안 (North Korean Disease Control Management System Establishment). Seoul: Tongilbu 통일부 (Ministry of Unification).

Yonhapnews. 2020. "WHO bukan, 10wol hyeonjae 1 man2cheonyeomyeong korona geomsa... hwakjinja eopseo WHO 북한, 10월 현재 1만2천여명 코로 나 검사... 확진자 없어 (WHO Said that in October, about 12,000 People were Tested for Coronavirus in North Korea and there were no Confirmed Cases)." Yonbapnews, November 10, 2020. https://www.yna.co.kr/view/ AKR20201110019300504.

Yun, Byeong-du 윤병두. 2020. "Bukanui hallyuyeolpung 북한의 한류열풍 (K-Wave in North Korea)." Nongchonyeoseongsinmun 농촌여성신문, December 11, 2020. http://www.rwn.co.kr/news/articleView.html?idxno=58033. 